\title{
The dermatitis by Caparinia tripilis and Microsporum, in african pygmy hedgehog (Atelerix albiventris) in Romania - first report
}

\author{
Dermatite induzida por Caparinia tripilis e Microsporum em ouriço pigmeu africano (Atelerix albiventris), \\ na Romênia - primeiro registro \\ Olimpia Iacob ${ }^{1 *}$; Adriana Iftinca ${ }^{2}$

\begin{abstract}
${ }^{1}$ Disciplina de Parazitologie și Boli Parazitare, Departamentul Clinici, Facultatea de Medicină Veterinară, Universitatea de Științe Agricole și Medicină Veterinară "Ion Ionescu de la Brad”, Iași, Romania

${ }^{2}$ Cabinet Medical Veterinar "Mihăilescu”, Constanța, Romania
\end{abstract}

Received March 10, 2018

Accepted June 19, 2018

\begin{abstract}
Investigations were conducted on a case of generalized dermatitis in an African pygmy hedgehog (Atelerix albiventris), purchased as a pet. Clinical examination revealed restlessness, agitation, itching and scratching, large alopecic areas, skin congestion and thin whitish scabs. Five skin lesions were scraped and the samples were collected for laboratory tests. Microscopy revealed the presence of the mite Caparinia tripilis (Acari: Psoroptidae). A dermatophyte belonging to Microsporum genus was also isolated by culture on specific media. Selamectin spot-on and enilconazole washes were used for treatment, resulting in skin healing and spines growing. To our knowledge, this is the first reported case of Caparinia tripilis dermatitis in a hedgehog in Romania.
\end{abstract}

Keywords: African pygmy hedgehog, dermatitis, Caparinia tripilis, Microsporum, first report, Romania.

\section{Resumo}

Foram conduzidas investigações em um caso de dermatite generalizada em um ouriço pigmeu Africano (Atelerix albiventris), comprado como animal de estimação. $\mathrm{O}$ exame clínico revelou inquietação, agitação, coceira e arranhadura, grandes áreas alopécicas, congestão da pele e escamas finas e esbranquiçadas. Cinco lesões de pele foram raspadas, e as amostras coletadas para exames laboratoriais. A microscopia revelou a presença do ácaro Caparinia tripilis (Acari: Psoroptidae). Um dermatófito pertencente ao gênero Microsporum também foi isolado por cultura em meio específico. Para o tratamento foram utilizadas aplicação tópica com selamectina e lavagens com enilconazol, resultando na cicatrização da pele e no crescimento dos espinhos. Possivelmente este é o primeiro caso relatado de dermatite por Caparinia tripilis em um ouriço na Romênia.

Palavras chave: Ouriço pigmeu africano, dermatite, Caparinia tripilis, Microsporum, primeiro registro, Romênia.

\section{Introduction}

The African pygmy hedgehog (Atelerix albiventris, Wagner, $1841)$ is an insectivorous nocturnal animal, which lives in the steppe and savannah areas in Africa (OKORIE-KANU et al., 2015). During the day the hedgehog shelters in galleries dug under the ground while feeding takes place at night. The diet consists mainly of insects (spiders), earthworms, snails and some plant material, the animals being omnivorous (PARKES, 1975;

\footnotetext{
*Corresponding author: Olimpia Iacob. Department of Parasitology and Parasitic Diseases, Faculty of Veterinary Medicine, University of Agricultural Sciences and Veterinary Medicine "Ion Ionescu de la Brad", no $8 \mathrm{M}$, Sadoveanu Alley, 700489, Iași, Romania. e-mail iacobolimpia@yahoo.com; oiacob@uaiasi.ro
}

IVEY \& CARPENTER, 2012). In recent years the African pigmy hedgehog has been introduced as a pet in many countries of the world (CARPENTER \& LINDEMANN, 2015) and is being more frequently seen in veterinary practices. Various diseases involving skin, fungal or pathological conditions with non-specific etiology have been reported (OKORIE-KANU et al., 2015). Dermatitis is particularly common with a prevalence of $66.04 \%$ (GARDHOUSE \& ESHAR, 2015).

Parasitic dermatitis is often found in hedgehogs due to infection with ectoparasites (ticks, fleas, mites) possibly due to the inability of the hedgehog to clean the skin. Acariosis is due to infection with mite species of the genus Notoedres, Sarcoptes, Chorioptes, Otodectes and Caparinia (MOREIRA et al., 2013). 
Hedgehogs are known hosts and natural reservoir for several species of pathogenic bacteria (Borrelia burgdorferi, Anaplasma phagocytophilum, Salmonella spp. Campylobacter spp.) and protozoans (Giardia and Cryptosporidium genus) with public health implications. The risk of transmitting infectious or parasitic agents to humans has risen by the increasing habit of keeping hedgehogs as pets. Direct contact with hedgehogs, litter, feed, contaminated pots or their excrements may contribute to human infection and the spread of zoonoses (KRAWCZYK et al., 2015; DZIEMIAN et al., 2015). The present study describes the first case of acariosis induced by Caparinia tripilis (Michael, 1889) (Acari: Psoroptidae) associated with Microsporum spp. in an African Pygmy Hedgehog (Atelerix albiventris), in Romania.

\section{Materials and Methods}

Investigations were conducted in 2015, in a private veterinary practice from Constanța and Parasitic Diseases Clinic of the Faculty of Veterinary Medicine Iasi, Romania, on a case of generalized dermatitis in an African pygmy hedgehog (Atelerix albiventris), purchased as a pet. The hedgehog, a 7 month old male, $560 \mathrm{~g}$ body weight, was clinically examined and parasitological and mycological investigations were performed. Clinical examination assessed the general health condition and severity of the cutaneous lesions and their occurrence on the body surface.

Five samples of cutaneous tissue, marginal to the areas of lesions were taken, clarified with lactic acid and used subsequently to obtain wet mounts. Examination and microphotography of the parasites were made using a Leica ICC $50 \mathrm{HD}$ microscope. Species identification and taxonomic classification of ectoparasites recovered from the skin were made based on morphological characters and morphometric parameters available in the literature (COSOROABĂ, 2000; KIM et al., 2012a; MOREIRA et al., 2013). Cultures from all cutaneous tissues samples were performed on Dermatophyte Test Medium (Merck, Germany).

Twelve miligrams of selamectin (Stronghold) were spoted-on to treat the hedgehog. As antifungal therapy, four general washes with enilconazole (Imaverol) 2\% were applied.

\section{Results}

Clinical examination revealed a poor general condition, lack of alertness (Figure 1A). On the face, neck and abdomen areas, the skin was congested, edematous and covered with fine, white and slightly sticky scabs (Figure 1B), extended on the fore and hind limbs to the base of the nail (Figure 1C). On the auricular concha, thick, deformed, whitish-yellow crusts were observed (Figure 1D). On the back side of the body, areas with diffuse alopecia and tendency to spread were observed; decreased number of spines or their complete fall was also noticed (Figure 1E). Itching led to scratching lesions, restlessness and appetite loss. Skin congestion and edema with fine, generalized, squamous crusts were also observed (Figure 1F).

Microscopic examination of dermal scraping revealed the presence of adult mites, immature stages, embryonated eggs and shells. C. tripilis includes mites with ovoidal globulous body, slightly dorso-ventral flattened, covered with a nude cuticle, without spines. The mouthpiece is small, adapted for stinging and sucking. The legs, four pairs, end with a short and ambulatory pedicle in the form of a cup. There is sexual dimorphism and the female is larger than the male. The egg is ovoid, colored pearly-white (Figures 2A and B). The larva has six pairs of legs provided with ambulacres (Figure 2C), the protonymph is octopod and sexually diferentiated; the female protonymph has a pair of postero-dorsal tubules for coupling (Figure 2D). The deutonymph or pubescent female resembles the protonymph.

The adult female or ovigera resembles the deutonymph female, but in addition, the genital opening on the ventral region at the level of coxa II can be observed. On the posterior edge of the body, lateral from the anus, there is the copulatory bursa in which fertilization takes place and two pairs of long setae (Figure 2E). On the dorsal region in the humeral area, there are two long setae fixed in small oval shaped shields (Figures 2F and G.). The adult male has the third pair of legs very long and the fourth, very short (Figure 2H). It has ambulacres on all pairs of legs and two posterior lobes. Each lobe is trilobed, provided with 3 long setae (Figure 2I). Also, the male has a pair of copulative cups (Figure 2I) with which they attach for fertilization (Figure 2J) and possess a sclerified, characteristic, dorsal posterior shield. The males and the deutonymphs form pairs and are coupled together until the moulting to the adult.

The morphological study confirmed that the identified mites were classified in the Astigmata order, Psoroptidae family, C. tripilis, this being the first record of infection of the African pygmy hedgehog in Romania.

Mycological cultures revealed numerous colonies of dermatophytes on Dermatophyte Test Medium. Microscopically aspects were consistent with a Microsporum spp. isolate. The follow up evaluation after 3 weeks revealed the efficacy of the treatment and healing of the patient (normal skin and spines).

\section{Discussion}

Acariosis induced by species of genus Caparinia has a wide geographical range in Europe (England, Germany), New Zealand, the United States of America, Asia and Korea, where it affects the hedgehog colonies raised as pet animals (BROCKIE, 1974; KIM et al., 2012a). Recently cases of acariosis on the African Hedgehog were reported from Poland (DEMKOWSKA-KUTRZEPA et al., 2013) and Costa Rica (MOREIRA et al., 2013). The genus Caparinia (Canestrini, 1894), Psoroptidae family, includes several species, among which the best known are $C$. tripilis and Caparinia erinacei (Fain, 1962). The species C. tripilis identified in England in the European hedgehog (Erinaceus europaeus), is more frequent among hedgehog colonies raised in captivity (KIM et al., 2012a).

The prevalence of acariosis induced by $C$. tripilis oscillates from $40 \%$ to $100 \%$ (FREDES \& ROMÁN, 2004), which suggest that this species would be considered as a normal ectoparasite on the skin of the hedgehog without causing clinical signs (GARDHOUSE \& ESHAR, 2015).

Clinical signs characterized by pruritus, congestion, edema, spine loss, crumbly deformation of the auricular conch and nail 

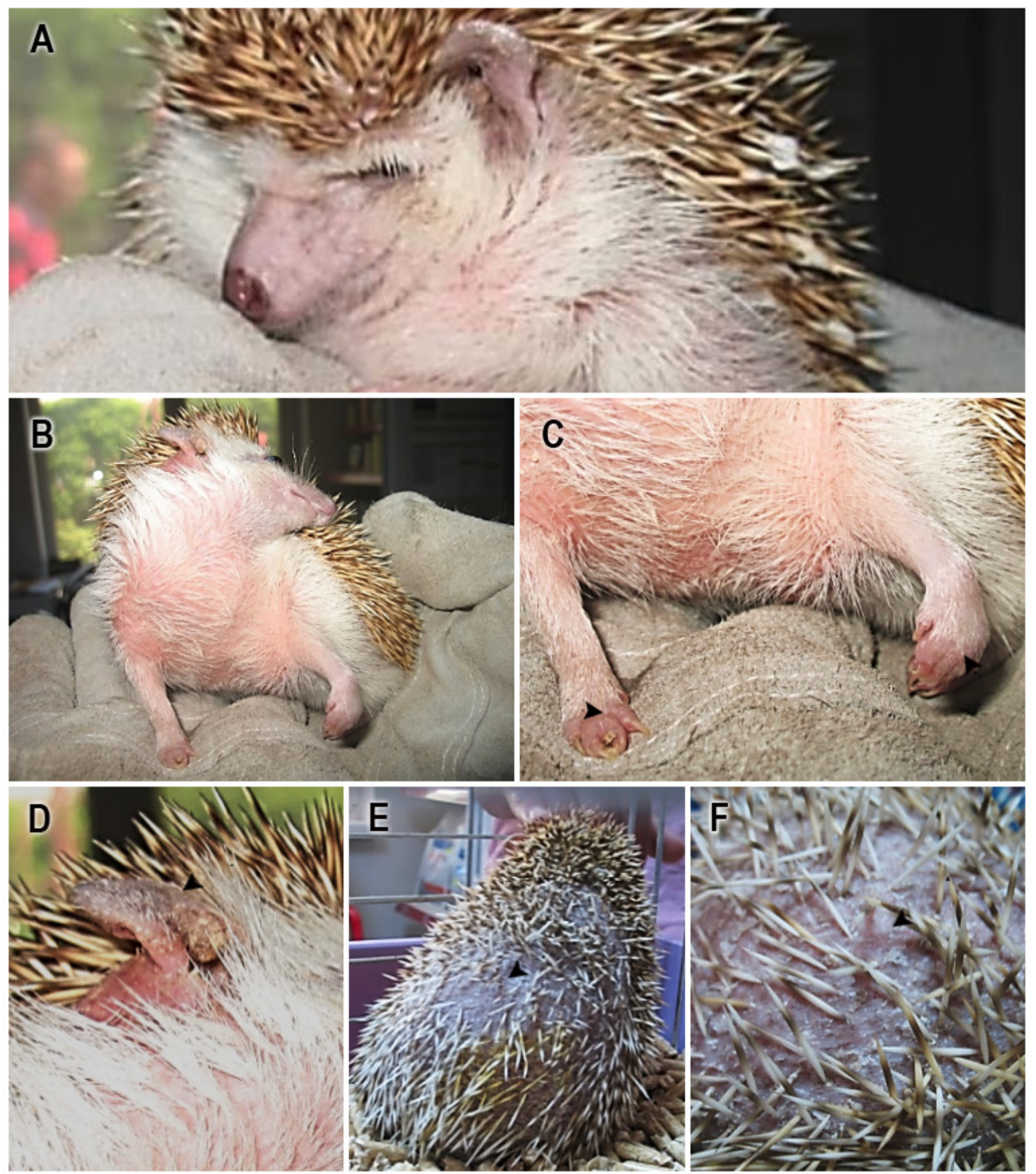

Figure 1. African Pygmy Hedgehog (Atelerix albiventris) with acariosis. A poor general condition, lack of alertness (A), squamous lesions, congestion and edema on the face, neck and thoracic area (B) skin to the base of the nail base (black arrows) (C), crusts lesions on auricular concha (black arrow) (D), and diffuse alopecia on the backside of the body (black arrow) (E), congestion, edema and squamous lesions-detail (black arrow) $(\mathrm{F})$.

base, crustaceous cuticular lesions associated with secondary infections, induced by $C$. tripilis, have been described in other studies (COSOROABĂ, 2000; KIM et al., 2012a), similar to the conditions described in this paper.

In the African pygmy hedgehog, dermatophytosis is frequently associated and is produced by the species: Trichophyton erinacei, Trichophyton mentagrophytes, Microsporum spp., and Arthroderma benhamiae, and characterized through lesions of dermatitis, occurrences of crusts, especially around the face and pinnae and the loss of spines. Some infections are secondary to other dermathopaties such as acariosis or trauma (CARPENTER \& LINDEMAN, 2015).

The concomitant evolution of acariosis produced by $C$. tripilis with dermatophytosis produced by species T. erinacei, Microsporum canis and Microsporum gypseum, have been reported (MOREIRA et al., 2013), as also observed here.

In this case, the African pygmy hedgehog diagnosed by us with acariosis produced by $C$. tripilis, associated with Microsporum spp., 


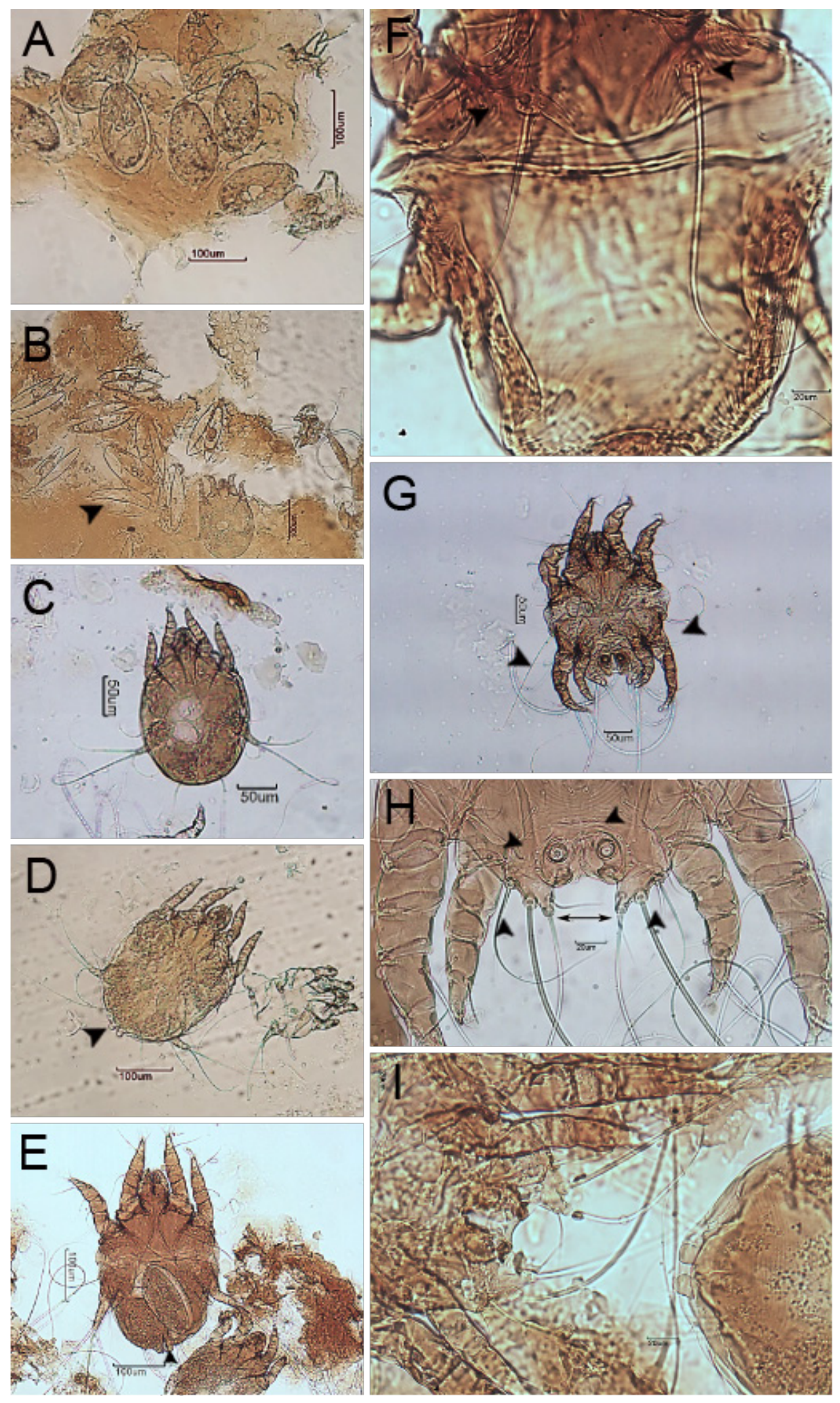

Figure 2. Caparinia tripilis, morphological details. Embryonated eggs, shells and immature stages (A, B). Larval stage (C). Protonimph female, posterior tubules (black arrow) (D). Adult or ovigera female (ventral) (E); on the posterior edge of the body, there is the copulatory bursa (black arrow) and two pairs of long setae; on the dorsal region, in the humeral area, has two long setae fixed in small oval distinct shields -dorsal view (F) (black arrows). The male has the third pair of legs very long (black arrow), and the fourth, very short (G), with ambulacre on all pairs, and two posterior lobes (double black arrows); each lobe is trilobed, provided with three long settae (single black arrows) (H); a pair of copulatory cups situated posteriorly (black arrow) $(\mathrm{H})$ with which attaches itself to the posterior tubers of deutonymphs (I), forming pairs. 
was treated with an avermectine and enilconazole, substances with maximum efficacy, which led to complete healing of skin lesions, our results being similar to those reported in the literature (MEREDITH, 2006; KIM et al., 2012b; EO et al., 2015).

Very good results in African pygmy hedgehog (Atelerix albiventris) therapy, infected with $C$. tripilis, by utilizing Fluralaner, in a single dose of $15 \mathrm{mg} / \mathrm{kg}$, orally administered with maximum efficacy, have been obtained (ROMERO et al., 2017).

Kim et al. (2012b) suggest the fact that the species $C$. tripilis does not have a zoonotic aspect, but can transmit dermatophytes to humans, but Weishaupt et al. (2014) communicate an unusual case of a person with T. erinacei, transmitted by the African pygmy hedgehog (Atelerix albiventris), that he held as a pet, drawing attention to the risk of human infection with dermatophytes. The choice of African pygmy hedgehog as pet requires knowledge of species and race, protection and biological comfort (PARKES, 1975; HEDLEY, 2011; IVEY \& CARPENTER, 2012).

The expansion and variety of options for exotic pets, contribute to the emergence and expansion of new morbid entities with new etiology. This case report highlights the presence of $C$. tripilis acariosis and a co-infection with Microsporum spp. in an African Pygmy hedgehog (Atelerex albiventris) being kept as a pet in Romania.

\section{Acknowledgements}

All my gratitude and special thanks to Professor David Rollinson for the suggestions and correction in English of this manuscript.

\section{References}

Brockie RE. The hedgehog mange mite, Caparinia tripilis, in New Zealand. NZ Vet J 1974; 22(12): 243-247. http://dx.doi.org/10.1080/ 00480169.1974.34179. PMid:4549591.

Carpenter JW, Lindemann D. Diseases of hedgehogs [online]. Kenilworth: MSD; 2015. [cited 2018 Mar 10]. Available from: https://www.msdvetmanual. com/exotic-and-laboratory-animals/hedgehogs/diseases-of-hedgehogs.

Cosoroabă I. Parazitologie Veterinară - Acarioze Entomoze. Timisoara: Ed. Mirton; 2000.

Demkowska-Kutrzepa M, Studzinska M, Tomczuk K. The first report of Caparinia tripilis among African pygmy hedgehogs (Atelerix albiventris) in Poland. Ann Parasitol 2013; 59: 65.

Dziemian S, Sikora B, Piłacińska B, Michalik J, Zwolak R. Ectoparasite loads in sympatric urban populations of the northern white-breasted and the European hedgehog. Parasitol Res 2015; 114(6): 2317-2323. http:// dx.doi.org/10.1007/s00436-015-4427-x. PMid:25820646.

Eo KY, Kwak D, Kwon OD. Treatment of mange caused by Caparinia tripilis in native Korean wild hedgehogs (Erinaceus amurensis): a case report. Vet Med 2015; 60(1): 57-61. http://dx.doi.org/10.17221/7927VETMED.
Fredes F, Roman D. Fauna parasitaria en erizos de tierra africanos (Atelerix albiventris). Parasitol Latinoam 2004; 59(1-2): 79-81. http://dx.doi. org/10.4067/S0717-77122004000100017.

Gardhouse S, Eshar D. Retrospective study of disease occurrence in captive african pygmy hedgehogs (Atelerix albiventris). Isr J Vet Med 2015; 70(1): 32-36.

Hedley J. African pygmy hedgehog care [online]. Peterborough: Vet Times; 2011 [cited 2018 Mar 10]. Available from: https://www.vettimes.co.uk/ article/african-pygmy-hedgehog-care/

Ivey E, Carpenter JW. African hedgehogs. In: Quesenberry KE, Carpenter JW. Ferrets, Rabbits and Rodents Clinical Medicine and Surgery. 3rd ed. St. Louis: Elsevier; 2012. p. 411-426. http://dx.doi.org/10.1016/B978$1-4160-6621-7.00030-0$

Kim D-H, Oh D-S, Ahn K-S, Shin S-S. An outbreak of Caparinia tripilis in a colony of African Pygmy Hedgehogs (Atelerix albiventris) from Korea. Korean J Parasitol 2012a; 50(2): 151-156. http://dx.doi.org/10.3347/ kjp.2012.50.2.151. PMid:22711928.

Kim K-R, Ahn K-S, Oh D-S, Shin S-S. Efficacy of a combination of 10\% imidacloprid and $1 \%$ moxidectin against Caparinia tripilis in African pygmy hedgehog (Atelerix albiventris). Parasit Vectors 2012b; 5(1): 1-8. http://dx.doi.org/10.1186/1756-3305-5-158. PMid:22871121.

Krawczyk AI, van Leeuwen AD, Jacobs-Reitsma W, Wijnands LM, Bouw E, Jahfari S, et al. Presence of zoonotic agents in engorged ticks and hedgehog faeces from Erinaceus europaeus in (sub) urban areas. Parasit Vectors 2015; 8(1): 1-6. http://dx.doi.org/10.1186/s13071-015-0814-5. PMid:25885888.

Meredith A. Skin diseases and treatment of hedgehogs. In: Paterson S. Skin diseases of exotic pets. Oxford: Blackwell Science Ltda. Blackwell Publishing Co; 2006. p. 264-274.

Moreira A, Troyo A, Calderón-Arguedas O. First report of acariasis by Caparinia tripilis in African hedgehogs, (Atelerix albiventris), in Costa Rica. Rev Bras Parasitol Vet 2013; 22(1): 155-158. http://dx.doi.org/10.1590/ S1984-29612013000100029. PMid:24252963.

Okorie-Kanu OC, Onoja IR, Achegbulu EE, Okorie-Kanu JO. Normal haematological and serum biochemistry values of African hedgehog (Atelerix albiventris). Comp Clin Pathol 2015; 24(1): 127-132. http:// dx.doi.org/10.1007/s00580-013-1870-x.

Parkes J. Some aspects of the biology of the hedgehog (Erinaceus europaeus L.) in the Manawatu, New Zealand. NZ J Zool 1975; 2(4): 463-472. http://dx.doi.org/10.1080/03014223.1975.9517887.

Romero C, Sheinberg Waisburd G, Pineda J, Heredia R, Yarto E, Cordero AM. Fluralaner as a single dose oral treatment for Caparinia tripilis in a pygmy African hedgehog. Vet Dermatol 2017; 28(6): 622-e152. http:// dx.doi.org/10.1111/vde.12465. PMid:28691193.

Weishaupt J, Kolb-Mäurer A, Lempert S, Nenoff P, Uhrlaß S, Hamm $\mathrm{H}$, et al. A different kind of hedgehog pathway: tinea manus due to Trichophyton erinacei transmitted by an African pygmy hedgehog (Atelerix albiventris). Mycoses 2014; 57(2): 125-127. http://dx.doi.org/10.1111/ myc.12113. PMid:23889168. 